\title{
Foreword: The Long Game
}

\author{
D. ALISSA TROTZ
}

For Maud Fuller, Jamaican-Canadian educator (1933-2013)

We could start with this story: A parent, herself a Black teacher, runs into her son's French teacher, who is white. She tells him that her son has transferred to one of the technical high schools. He congratulates her, assuring her that she has made the right decision since - he tells her confidently - her beloved child will be good with his hands.

Or we could begin by introducing a Black university student, also a parent, who leaves her seminar discussion almost every week as she keeps getting calls from her child's school about his disruptive behaviour. At one point, her son is physically restrained by a teacher. Efforts to challenge this - including contacting the school superintendent continue all year. Unsatisfied with the responses she has received, she eventually transfers her son to another school, making her commute to his school and her university significantly longer. No changes are made at her son's former school.

Another student-parent learns that her son has been moved to a special education classroom without consultation. The special ed class is taught by the school's only Black teacher, and most of the students in that class look like her child.

The children in the above two stories are both five years old.

Or we could simply begin by reflecting on what it means to be a parent of Black children in North America, what it means to watch them grow into an understanding of themselves as part Caribbean - as affirmation to be sure, but also as the expression of a tentative relation to a place where they were born and raised and schooled.

School (noun). A space where Black parents are acutely aware that our children spend most of their waking weekdays. Where big pieces of them are (de)formed. A space of damage. Where we are yet to understand the spiritual and psychic costs, even as we know that racism and 
mental health are inextricably linked (see Sinai Health System, Human Rights \& Health Equity Office, 2017; Taylor \& Richards, 2019).

School (verb). To put a person in their place.

Add up the experiences. Multiply the slights that are not slight at all. Divide and subtract. Take away the sense of a self that is valuable. This is not an abstraction.

In this thoughtful collection, Carl James walks us through the difficult calculus of young Black lives. The essays gathered here were published over the course of two decades and represent research with young people in Ontario conducted over an even longer period - across NDP, Liberal, and Conservative governments. Taken together, these essays give rise to a temporal dissonance that is, to say the least, disconcerting: on one hand, the awful immediacy of the issues foregrounded in these pages; on the other, the long horizon of anti-Black racism. This dissonance is underlined in the chapters that track the subduing of Black aspiration in longitudinal surveys with young people. The essays are punctuated by responses from other Black educators, with titles that underline congruence across time and Black diasporic space ("It Could Have Been Written Today: A Montrealer's Reflection"; "It's the Same with Black British Caribbean Pupils"; "Black Lives Matter in the USA and Canada"). The final essay, on consultation sessions with members of Black communities in the Greater Toronto Area in 2016, seems to reprise decades-old issues covered in earlier chapters. And the urgency of the times we inhabit - let us be clear, this is a state of emergency - is most starkly conveyed in the evidence James offers us, from Toronto District School Board figures, that when it comes to suspension, expulsion, and dropout rates, the figures are higher for succeeding generations of Black children (chapter 2). What these data tell us, to put it bluntly, is that the longer Black folk are here, the worse it becomes.

In meticulous detail, and drawing on primary and secondary research, James lays out the materialization of anti-Black racism. This is the storying of how the Canadian school system produces the Black child as a problem, as academically inferior and unteachable. It does this via a series of systemic practices: stereotypes (like the trope of the Black male as immigrant, fatherless, athlete, troublemaker, underachiever); streaming; surveillance (in her response to chapter 8, Adelle Blackett describes this as "perpetual policing," which moves from street to school and back again); suspicion; suspensions; and "safe schools" acts that, in operating to evict, render schools anything but safe for Black children. The absence of representation in the official curriculum, barely disrupted by 
compartmentalized multicultural pedagogies like the annual celebration of Black History Month, provides an early lesson to all children on whose lives count and which communities are valuable. The damage is deepened via what has been described as the "hidden" curriculum of misconceptions and culturally biased attitudes that shape teachers' interactions with and expectations of their Black students (see Aladejebi's response to chapter 1) - surely a misnomer, since nothing is hidden when we take into account what a child hears, sees, senses, and feels.

In these pages, we also see how anti-Black racism is deftly reconfigured when challenged, as in the example James offers of how, when faced with the official recording of suspension rates, several schools simply shifted to other forms of exclusion that flew under the radar, and that even included attempts to "encourage" Black parents to voluntarily relocate their children. He shows how neoliberal logic obscures enduring structures of anti-Black racism, returning us to cultural deficit models that valorize and place responsibility on the individual (the Black mentor, the Black role model, the all-you-need-to-do-is-putyour-head-down-and-work Black student), while putting the blame for so-called Black underachievement on Black communities and on Black families in particular. And he lists an avalanche of official reports, royal commissions, consultations, strategies, legislation, working groups each succeeding intervention a rehearsal of what we already know. While calling for a response, the reports themselves become the sum total of the response, instantiating erasure through acknowledgment. Coming with promises but no resources, the recommendations constitute the action meant to subdue and reassure, the action that turns out to be no action at all (Ahmed, 2012).

In tracking the operation of white supremacy in the Canadian school system, it is important for us to simultaneously attend to aggregation (showing how anti-Black racism universally produces the Black student as inferior and unbelonging) and disaggregation (properly attending to differences among Black students through an intersectional approach). In her response to chapter 1, Funké Aladejebi offers crucial insights into what this might look like across gender, geography, and itineraries of Blackness that speak to the specificity of Canadian-, Caribbean-, and continental-African-born youth. Drawing primarily on and making space for the experiences and voices of Black male youth living in the Greater Toronto Area, the book does an excellent job of laying out the deeply restrictive and pathologized notions of masculinized heteronormativity with which they must contend, raising other crucial questions of the consequences of such tropes for cis and trans girls and gender-nonconforming youth (Maynard, 2017). 
Some of the response essays further develop this point, noting that an emphasis in the literature on Black male youth can sometimes run the risk of eliding the varied production of Black femininities. In this text, James recognizes the importance of explicating the specific ways in which Black girls, as students, experience and navigate the Canadian school system (see introduction and chapter 9). These are urgent considerations, requiring us to attend to how Black children are differently disciplined by the gender and sexual politics of respectability and social mobility. What corresponding stereotypes attach themselves to Black female-presenting bodies? How does the trope of the absentee father as explanation for Black "underperformance" also require denigrating Black mothers and pathologizing households where the only adults are women?

Another area that calls for more detailed consideration is that of the deeply gendered circuits of social reproduction that offer support and care for Black children in and out of school. Again, some of the responses offer a glimpse into these support networks, such as the "othermothering" practices of Black women teachers as identified by Funké Aladejebi (response, chapter 1). With this in mind, we might reread Carl James's interview with Mark, a 1.5 generation (that is, immigrated to Canada between the ages of eight and twelve) Caribbean Canadian, for the clues it supplies about the affective and material support of his mother. Centring Mark's mother's migratory journey from Trinidad and Tobago yields a different kind of narrative, one that foregrounds transnational familial relationships that are central to the reproduction of Caribbean diasporic space and belie truncated and nation-bound notions of the single-parent household (chapter 3 and response by Amoaba Gooden). Such an approach might also compel us to revisit and renarrate the story of the mobilization of Black communities that is presented to us in chapter 1, exploring instead why and how women were often at the forefront of this organization that centred Black children's needs. It offers an alternate entry point into thinking across spaces and communities, and listening for the lessons that emerge about the unwaged, caring, invisible, and deeply gendered labour that is the foundation of the frontlines of struggle.

As is poignantly captured in these pages, education has long been held up for Black communities as a space for redressing inequities, a route to social mobility, intergenerational stability, and security. It unfolds here in multiple ways: in the dreams of families who migrate from the Caribbean in the hope of ensuring what they imagine to be better futures; in the savings of those who scraped together enough to move to the suburbs - many escaping the deepening racial and class 
inequalities produced by the displacement of gentrification - to give their children a better start. And repeatedly we see how aspirations are thwarted, how the meritocratic promise of individual effort is short-circuited by the structural persistence of anti-Black racism, and how suburban respectability comes at a price paid by Black students.

The cruel irony is that when "success" comes, despite all these roadblocks, and as exception rather than rule, it is held up in some quarters as singularity detached from collectivity, and as evidence that we inhabit a postracial world where brains and hard work are all it takes. When in fact - and this is "the heart of the matter," as James Baldwin observed - the young Black people whose lives are the point of departure in this collection are interpellated by a system designed to fail them, a system that requires them not "to aspire to excellence ... [but] to make peace with mediocrity" (Baldwin, 1963/1992, p. 4).

We would do well to recall Ruth Wilson Gilmore's (2007) incisive definition of racism as "the state-sanctioned or extralegal production and exploitation of group-differentiated vulnerability to premature death" (p. 247). In other words, this is not an aberration. Education as liberation thus comes up against the school as a key site for the social reproduction of inequality. This is a tension that James recognizes (see, in particular, chapter 4). And it therefore requires that we attempt to be as clear as possible about the questions we pose and the terrain we are fighting upon. I write this as a Black educator at the University of Toronto, an institution that trains large numbers of the teachers who populate our schools and is continually ranked as one of the top academic institutions in the world. At the very same time, it is a space from which, as Carl James points out in this volume, only 51 per cent of Black students who entered from the Toronto District School Board between 2004 and 2016 graduated (chapter 2). What - and who - must be disappeared for the celebratory narrative to hold? What does this moment, and "facts" like these, demand from us? As Sylvia Wynter (1992) said to her colleagues in the face of the 1992 Los Angeles riots and the disclosure that the police used NHI - No Humans Involved - as a code to refer to young Black men they apprehended and whose rights they routinely violated, "What are we, as grammarians of our present epistemological order, to do?"

In her response to chapter 4, drawing on Toni Morrison and Sylvia Wynter, Joyce E. King underlines the importance of reframing how we tell these stories, to "disconnect the implicit language of dominance ... from a vocabulary that Wynter theorizes ineluctably affirms the supposed inferiority of conceptual Blackness in alter ego relation to conceptual whiteness." King makes a compelling argument for the use of "action 
verbs instead of descriptive adjectives and nouns" (e.g., absented fathers, absented histories, impeded achievers, resource-starved, impoverishment). Such language can consistently direct a method and mode of analysis that uncompromisingly names the settler colonial context of Canada and the culturally lethal practices stitched into the seams of this country's educational system that fall with particular weight on Indigenous and Black communities.

Taking the frame of racial capitalism and the Black radical tradition as a point of departure enables us to see education as part of what James notes is "a capitalist system which [produces] large populations of unemployed, working-class, poor, and racialized youth" (chapter 5). It teaches us that confronting anti-Black racism is not a piecemeal endeavour, and that the seductive politics of inclusion and accommodation are highly selective, legitimizing ongoing systematic dispossession and exploitation while deepening class and other divides within the Black community. And this framework also cautions us against occasional slippages, such as when James refers to studies that quantify the cost of students' not completing high school, inadvertently deploying neoliberal logic to make a case for supporting Black student success as the "cheaper" option (chapter 10).

James opens this book with a historical overview of the educational experiences of Black youth, a discussion that gestures to the important work of initiatives and organizations. While he recognizes that it is not the largesse of successive governments but the insistent interventions of Black folk that has produced some changes (like the introduction of the Africentric Alternative School), this book does not specify the kind of sustained work this entails. The task of dismantling structures that deny Black people's humanity also requires the careful gathering-up of archives of contestation and reading them in relation to the household, the neighbourhood, the school, the school board, the city, the province, the country, and beyond. This is not just an exercise in rendering Black resistance visible - although that is surely important, particularly when it comes to the deeply gendered caring work. It also holds the promise of better understanding the conditions of possibility; of exploring the processes through which demands for change can get dissolved via incrementalism or the institutional politics of incorporation and reform (see, for instance, the thoughtful response to chapter 7 by Sam Tecle in which he reckons with the necessity, peril, and promise of the "Black mentor"); of thinking about the spaces for coalition-building; and of being clear-eyed about short-term demands while always keeping an eye on the long game, however far off the horizon and however much others might dismiss it as wishful thinking. The responses that follow each 
chapter foreground the transnational dimensions of the Black diaspora; in our examination of how students come to understand themselves as Black in school, it is imperative that we carefully map the connections across these experiences and movements across space and time.

In the opening chapter, Carl James gestures to the transnational dimensions of anti-Black racism and names Black British struggles in the 1970s and 1980s. One of the references he mentions is a 1971 pamphlet by Bernard Coard titled "How the West Indian Child Is Made Educationally Sub-Normal in the British School System." The pamphlet was published by New Beacon, one of the first Caribbean and African diasporic publishing houses in the UK and part of a sturdy infrastructure of Black organizing that was deeply diasporic in terms of both the migratory trajectories of the parents, students, and community activists involved and the international relations that informed collective practices in specific places (Walcott, 1997). The British school system was part of a colonial apparatus that also structured the curriculum in Coard's Grenada. Eight years after that pamphlet was issued, Bernard Coard, who by then had returned to the Caribbean, would be part of the New Jewel Movement's successful overthrow of Eric Gairy's oppressive regime in Grenada. At a lecture titled "The New School" given at the University of London's Institute of Education in July 1983 (later published in Coard, 1983), just a few months before the revolution's catastrophic implosion and the US invasion that followed, Coard emphasized that a central plank in the Grenadian government's efforts to transform independence into meaningful economic, political, cultural, and spiritual decolonization was the overhaul of the education system. He ended his talk with a quote from the Cuban philosopher José Martí: "The new world requires the new school."

I close by foregrounding this other geography, this different yet connected and as yet tragically unrealized horizon, as a way of reminding us perhaps of what is ultimately at stake in the work that we must keep doing, and how challenging anti-Black racism in our schools is part of the ongoing work of bringing entire new worlds into being. Education - both as and for liberation - is insurgent work. In the contexts so painstakingly elaborated upon in this important text, we ask: What is the long game and how do we get there?

\section{REFERENCES}

Ahmed, S. (2012). On being included: Racism and diversity in institutional life.

Durham, NC: Duke University Press. 
Baldwin, J. (1992). My dungeon shook: Letter to my nephew on the one hundredth anniversary of emancipation. In The fire next time (pp. 1-10). New York, NY: Vintage Press. (Original work published 1963)

Coard, B. (1971). How the West Indian child is made educationally sub-normal in the British school system. London, UK: New Beacon Books.

Coard, B. (1983). The new school. In Revolutionary Grenada: A big and popular school (pp. 9-24). London, UK: Spider Web.

Gilmore, R.W. (2007). Golden gulag: Prisons, surplus, crisis, and opposition in globalizing California. Berkeley: University of California Press.

Maynard, R. (2017). Policing Black lives: State violence in Canada from slavery to the present. Halifax, NS: Fernwood.

Sinai Health System, Human Rights \& Health Equity Office. (2017). Black experiences in health care: Symposium report. Toronto, ON: Author. https:/ / www.mountsinai.on.ca/about_us/human-rights/pdfs/SHS-BEHC-report -FINAL-aoda-final.pdf

Taylor, D., \& Richards, D. (2019, May 15). Triple jeopardy: Complexities of racism, sexism, and ageism on the experiences of mental health stigma among young Canadian Black women of Caribbean descent. Frontiers in Sociology. https:/ / doi.org/10.3389/fsoc.2019.00043

Walcott, R. (1997). Black like who? Writing Black Canada. Toronto, ON: Insomniac Press.

Wynter, S. (1992, Fall). No humans involved: An open letter to my colleagues. Voices of the Black Diaspora: The CAAS Resarch Review, 8(2): 13-16. https:// www.newframe.com/long-read-knowledge-must-mutate-be-fully-human/ 